\title{
Cuerpo extraño en pene
}

\author{
Jalón Monzón A, Álvarez Múgica M, Rodríguez Martínez JJ, Martín Benito JL, \\ González Âlvarez RC, Regadera Sejas FJ.
}

Urología-1. Hospital Universitario Central de Asturias. Oviedo. Asturias.

Actas Urol Esp 2006; 30 (4): 430

$\mathrm{V}$

arón de 26 años que acudió a urgencias por dolor en pene. Refirió haber estado afilando una guadaña, notando bruscamente dolor en pene. A la exploración presentaba una pequeña herida contusa de 3-4 $\mathrm{mm}$ en mitad anterior y dorsal del cuerpo del pene, con hematoma circundante. Se realizó una radiografía de pene (Fig. 1), donde se evidenció cuerpo extraño metálico en el espesor del pene. Con anestesia local y una pequeña incisión a través del orificio de entrada, se extrajo una esquirla metálica procedente del filo de la guadaña.

Dr. A. Jalón Monzón

E-mail: ajalonm@hotmail.com

(Trabajo recibido el 15 de julio de 2005)

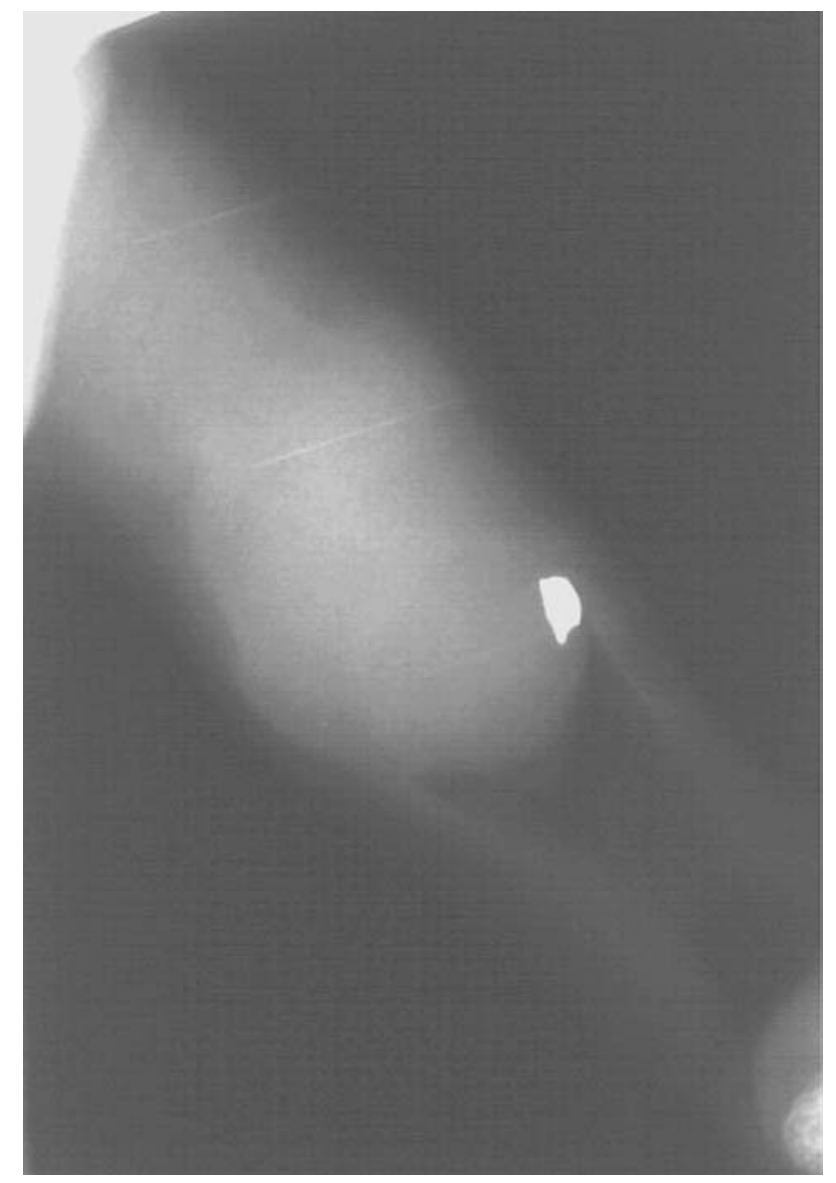

FIGURA 1 